\title{
Political Parties and the Power of Money in Indonesia and Beyond
}

\author{
Thomas Reuter
}

\begin{abstract}
Political parties in Indonesia and in other parts of Southeast Asia have become vitally dependent on the financial support of individuals or conglomerates with large private fortunes. A remarkable new development is that some of the billionaires who have long sponsored political parties have decided to out themselves as political leaders, and thus to adopt the style of oligarchs. I define an oligarchy as a society featuring systematic conflation of political and economic power within the same individuals or within small, elite groups of such individuals in a manner that is visible, tolerated and hence legitimated. The gradual shift from clandestine money politics to open oligarchy is a significant challenge for contemporary liberal democracies. Conflicts of interest between the demands of public office and their private interests would seem difficult to avoid for politicians who also run large business empires and own great estates. On the other hand, for billionaire sponsors of political parties to come forward and stand for public office personally also means that their hitherto clandestine influence is becoming more transparent, and their conduct and decisions more subject to public scrutiny and accountability. This article describes how both direct and indirect ways of conducting money politics operate and coexist within different types of political parties in Indonesia today, and what the significance of these differences is and what is changing; with special reference to the 2014 parliamentary elections in Indonesia.
\end{abstract}

KEYWORDS: Oligarchs, political parties, money politics, democracy, Indonesia

\section{INTRODUCTION}

$\mathrm{T}$

HIS ARTICLE EXPLORES THE state of political parties in Indonesia today, against the backdrop of the 2014 parliamentary elections. It is argued that political parties in Indonesia, as in other parts of Southeast Asia, have become severely dependent on financial support from individuals or conglomerates with large private fortunes. A remarkable new development in the world of money politics is that some of the billionaires who have been acting as financial sponsors of 
political parties for some time no longer seem content to operate invisibly. Many, in Indonesia and elsewhere in the region, have decided to out themselves as political leaders, and thus to adopt the style of oligarchs. The term 'oligarchy' is used in diverse ways in the literature (Winters 2011; Gunn 2014). For the purpose of this article, however, I define an oligarchy as a society featuring systematic conflation of political and economic power within the same individuals or small, elite groups of such individuals in a manner that is not clandestine but visible, accepted or at least tolerated, and hence held to be more or less legitimate. Oligarchs can and do influence not only politics as such but also the judiciary, military and civil society. The legitimacy of oligarchs is a controversial issue in all oligarchies that operate through a formally democratic system of government: not controversial enough to circumvent the exercise of oligarchic power but controversial enough still to keep some of its operations hidden.

This partial shift from clandestine money politics to open oligarchy has very significant consequences for the viability of liberal democracies and is impacting dramatically on the fate of ordinary citizens in many countries. Indeed, escalating conflation of political and economic power could be described as the core challenge for all contemporary democracies. While some may be more resilient to monetization than others, this is a matter of degree and not principle. How oligarchy operates in non-democratic political frameworks shall not concern me in this article. ${ }^{1}$

Conflicts of interest between the demands of public office and their private interests would seem difficult to avoid for politicians who also run large business empires or own great estates. Conflicts and biases arising from the unique positioning of these individuals thus can undermine the actual or at least the perceived integrity of democratic government - a form of government wherein holders of public office are assumed to leave their private interests behind when they take their oath. This is a tall order for business tycoons whose investments tend to be so widely diversified that almost all political decisions impinge on their private interest in one way or another, directly or indirectly. On the other hand, the new trend for billionaire sponsors of political parties to come forward and stand for public office personally also means that the extent of their hitherto clandestine influence is becoming more transparent, and their conduct and decisions more subject to public scrutiny and accountability. Such is the ambiguity of the contemporary trend toward oligarchy.

The following article provides an account of how direct and indirect models for conducting money politics operate and coexist within different types of political parties in Indonesia today, and what the significance of these differences is. This case study draws on five years of ethnographic research among the

\footnotetext{
${ }^{1}$ There is a large body of literature in particular about oligarchs in post-Soviet Russia and former Soviet Republics (e.g. Hoffman 2001; Gurief \& Rachinsky 2005). A comparison of this literature with studies of more democratic systems would be complex but valuable.
} 
Indonesian political elite and, more specifically, on my study of political processes surrounding the 2014 parliamentary elections. Prior knowledge of Indonesian politics is not assumed, so as to ensure the case study is accessible for comparative purposes to fellow students of politics and society across Southeast Asia and beyond. Before I begin to describe the Indonesian case, however, I first would like to contextualise it in wider regional and global contexts.

\section{Inequality and Money Politics in Southeast Asia: Regional vs. Global Issues}

In the only comprehensive and recent comparative study of money politics in political parties across eight ASEAN member states the editor, W. Sachsenroeder (2014: 4), warns that: "The risk of individuals and groups using political parties and state funds for personal gains is pervasive, and can compromise the economic strides that have been achieved in the ASEAN member states in recent decades." Money politics, he argues, also could undermine the ASEAN Charter of 2008, which sets out normative standards of democracy, rule of law and good governance to shape a positive future for the region. The present case study serves to reiterate this warning with respect to Indonesia. However, unlike Sachsenroeder, who stresses the low ranking of Southeast Asian nations in the Economist Intelligence Unit's Democracy Index 2011, I argue that the problem of money politics is systemic at a global level and cannot be fully understood as a national or even as a regional issue. Indeed, the results of the same index show that "democracy has been under intense pressure in many parts of the world. In most regions the average democracy score for 2011 is lower than in 2010, including the developed countries of North America and Western Europe [as well as Asia]." Money politics in political parties was found to be a major contributing factor across the board.

This is not to say that ASEAN nations lack distinctive national and regional characteristics, reflected also in party politics. Regional characteristics include a relative lack of a clear, European-style ideological distinction between parties along a left-right wing axis, the greater role of ethnically or religiously defined centre-periphery dynamics within nation states, strong cultural support for the positive normative aspect of patron-client relations, and the greater role of dynastic succession in political elite families with charismatic founders. None of these features are necessary or sufficient either to produce money politics and the rise of oligarchs, or to prevent it. Culturally and historically conditioned features of societies do have an impact, however, on the specific way in which money politics manifests, and on how it needs to be analysed, within the

${ }^{2}$ 'The Democracy index 2011: Democracy under stress.' Economist Intelligence Unit. Available at: http://www.eiu.com/public/topical_report.aspx?campaignid=DemocracyIndex2011 (accessed on 1 October 2014). 
region. In focusing on regional characteristics where appropriate, this case study thus has methodological relevance for other Southeast Asian political studies, while also stressing the overarching influence of global conditions.

My research also does not confirm another widely held assumption, that the democracies of Southeast Asia are weak because they are relatively new and lacking in institutionalisation, compared to older European democracies. For example, citing data from Africa, Basedau and Stroh (2008:6), recently proposed that "more institutionalized parties perform more favourably as regards their functional duties than less institutionalized parties do". Significant differences in degree of institutionalisation do exist in Indonesia, between the post-1998 parties and the long established Golkar Party, for example. This does not seem to impact on the prevalence of money politics (see below), and it matters, insofar as one cannot reasonably expect a party to meet its functional duties in the public interests if it is controlled or owned by private capital.

In broader, theoretical terms, the important role of political parties in promoting or undermining democracy has been well documented and long discussed by political scientist including Duverger (1956), Lipset and Rokkan (1967), Lijphart (1968), Sartori (1976), Panebianco (1988), Huntington (1991) and many others, and need not concern us further. Money politics is also clearly recognised as a key variable by most commentators. There is considerable debate amongst these authors, however, as how we can best analyse the threat to democracy in terms of cause and effect. This is often a question of methodology.

Schlozman et al. (2012) have presented data on economic inequality and public opinion to show that the United States now ranks among the least egalitarian of Western democracies and to prove that national policies are skewed in favour of the ultra-rich. They explain this finding in terms of the much greater opportunity for regular political participation available to the latter. For Jeffrey Winters (2011), however, this approach is flawed because the lion's share of recent gains in income and wealth have gone to a tiny sliver of the population, the top $1 / 10^{\text {th }}$ and even $1 / 100^{\text {th }}$ of the top one per cent of households. If political participation were the cause, economic gains should have been diffused more widely to include the upper middle class, which has every opportunity to participate in democracy in the ordinary sense. This is not the case. Instead, Winters argues, policies enacted as a direct result of the oligarchic influence of a small minority of individuals are the main explanation for the increased concentration wealth.

There is also much debate about the extent of the consequences for democracy. Fortunately, as even Winters is happy to fellow oligarchs do not agree on a great many political issues, hence he concludes that we now have the civil equivalent of a warring oligarchy. This caveat offers small comfort however, in the light of recent events in Thailand, for example, where the oligarch, Thaksin Shinawatra, with an estimated wealth of $\$ 1.7$ billion USD, was able to finance systematic protests on a massive scale, ending in a collapse of 
democracy. Whether we agree with Thaksin's agenda or not, this case shows the powerful disruptive effect large-scale private investments in politics can have. ${ }^{3}$ Thomas Rhoden's (2013) comments on the Thai case hint at the futility of debates about cause and consequence: "This is not to ask does everything in Thai national politics happen because of a few extremely wealthy Thai oligarchs, but instead to ask the counterfactual: If extreme inequalities of material wealth were not an empirical reality in Thailand, then would events be playing out as they are right now?" Clearly, inequality is both the cause and the effect of a distinct set of private interventions in democratic processes, and because of this feedback, the overall dynamic is one of stochastic escalation.

Finally, when it comes to addressing issues such as money politics and the rise of oligarchs, the opinions of expert commentators diverge even further. This reflects a lack of comparative data on how exactly oligarchy and clandestine forms of money politics are produced and reproduced through the mechanics of practical party politics. The present article seeks to make a modest contribution toward meeting the urgent need for such in-depth research, and thus makes no excuse for focusing on just one country, Indonesia.

\section{Indonesia's Legal Framework AND the 20 I 4 Election}

One way to understand why political parties have become ultra-permeable to private capital in Indonesia is to look at the formal legal framework. This is also important because many experts' suggestions for remedying money politics come down to proposals for changing legal frameworks through new legislation. This case shows that such formal adjustments can be ineffective and fraught, and that policy frameworks need to be explored in terms of their actual impact on elections.

Indonesia has tightened election participation rules in recent years, and consequently the number of political parties eligible to contest national elections has dropped from 48 in 1999 to 12 in the most recent, 2014 election. The policy intervention has fulfilled its aim of preventing a proliferation of small parties, and Indonesia thus has avoided the classical problem of systemic vulnerability due to fragmentation, made notorious in political history by the of the Weimar Republic into fascism in 1930s Germany. On the downside, however, onerous participation requirements have vastly increased running costs for parties and have made democratic politics prohibitively expensive.

Legislative elections in Indonesia are guided by 'Law No. 8 of 2012'. Representatives to the national assembly (DPR) are elected under an open-list

\footnotetext{
${ }^{3}$ South Korean businessman, Chung Mong-Joon (Hyundai group), is another example. With a net worth of US $\$ 1.6$ billion, Chung Mong-Joon has become a successful politician, a member of the National Assembly of South Korea in his fifth term in office, and a presidential candidate in the 2012 election. As a representative of the Saenuri Party, he recently expressed support for nuclear armament of South Korea, which could destabilise an already precarious security situation.
} 
proportional system through affiliation with political parties. To be eligible to contest an election, Article 8 of this law requires political parties to meet the following conditions (summary only):

1. Having met the threshold of 3.5 per cent of national votes in the last election.

2. Political Parties that did not meet the threshold in the previous election or are newly established may contest an election if they have:

(a) regional chapters in all provinces;

(b) chapters in $75 \%$ of regencies/municipalities in these provinces;

(c) chapters in $50 \%$ of districts/kecamatan in these regencies/ municipalities;

(d) have 1000 registered members for each chapter of the political party;

(e) at least $30 \%$ women's representation in the management of the central chapter of the political party, and among candidates for election.

For 2014, having met the above conditions, the General Elections Commission (Komisi Pemilihan Unum, KPU) approved only the following twelve parties to contest the national elections:

- Golkar (leading party of the Suharto era, chair: business tycoon Aburizal Bakrie)

- Indonesian Democratic Party of Struggle (PDI-P, chair: Megawati Sukarnoputri)

- Great Indonesia Movement Party (GERINDRA, chair: Prof. Dr. Ir. Suhardi; founder and presidential candidate: former general Prabowo Subianto)

- Democratic Party (PD, chair: President Susilo Bambang Yudhoyono alias 'SBY')

- People’s Conscience Party (HANURA, chair: former general H. Wiranto)

- National Democrats (Nasdem, chair: media tycoon Surya Paloh)

- Justice and Unity Party (PKPI, chair: former general \& Jakarta governor Sutiyoso)

- Prosperous Justice Party (PKS, chair Muhammad Anis Matta)

- National Awakening Party (PKB, chair: HA Muhaimin Iskandar)

- National Mandate Party (PAN, chair: minister of economics M. Hatta Rajasa)

- United Development Party (PPP, chair: Dr. H. Suryadharma Ali)

- Crescent Star Party (PBB, chair: Prof Yusril Ihza Mahendra)

The biggest winner to emerge from the 2014 elections was Gerindra, whose leader Prabowo Subianto had led an aggressive and very expensive media campaign, focusing on the plight of those left behind by Indonesia's recent economic boom. Another winner, with the largest overall percentage of votes, was 
PDIP - boosted by the late nomination of popular presidential candidate Joko Widodo, also known as 'Jokowi,' though less so than had been expected. The greatest loser has been the ruling Democrat Party (PD) of former general and outgoing President Susilo Bambang Yudhoyono, popularly known as 'SBY'. The new Nasdem party of billionaire Surya Paloh made a strong entry. 'Islamic identity' parties (last five on the above list) remained fairly stable but small. ${ }^{4}$ $\mathrm{PKB}$, a nationalist Islamic identity party, recovered somewhat after a period of internal conflict. These results are shown in Table 1, with the main winners marked in bold and the main loser underlined.

Only parties and coalitions with at least 25 per cent of the vote, or 20 per cent of seats in the House of Representatives (Dewan Perwakilan Rakyat, or DPR) are able to field a presidential candidate. Not even the largest party, PDIP, was able to meet this condition in 2014. The Constitutional Court has scrapped the requirement for the 2019 elections, with a decision to hold concurrent legislative and presidential elections. For the time being, the rule forces political parties to seek alliances, especially by offering the vice-president ticket and ministerial posts to another party.

In the aftermath of the 2014 election, the following two large inter-party alliances formed in preparation for the presidential election later in the same year: PDIP-PKB-Hanura-Nasdem-PKPI vs. Gerindra-Golkar-PAN-PKS-PPP. Yudhoyono's decimated PD was non-aligned as of 30 May 2014. The presidential and vice-presidential candidate teams of the two alliances were Jokowi-Kalla vs. Prabowo-Hatta Rajasa. The second of the two alliances was by far the stronger. Party support, however, is not a reliable predictor of voter behaviour, as was made evident in the 2013 election that saw Jokowi rise to the office of Governor of Jakarta despite a majority alliance of parties supporting his opponent. The presidential election of 2014 would prove to follow the same pattern. The more popular Jokowi-Kalla presidential team won by a narrow margin, despite the much greater size of their opponents' political party coalition and their somewhat greater financial support. However, unless the coalition behind the losing Prabowo-Hatta team collapses, the new president Jokowi will face a hostile parliament, with only 207 out of 560 seats gained by his alliance, and thus have limited effectiveness. A recent decision by parliament to revoke the law on direct regional election against Jokowi's wishes suggests he will face staunch opposition or worse. This means that the presidential system in Indonesia, even under a populist like Jokowi, and much like the US under President Obama, cannot compensate for the power of the House of Representatives and for the systemic captivity to powerful private interests of the political parties operating therein.

\footnotetext{
${ }^{4}$ The term 'Islamic' party is of little practical use, because there is very little by which these party's can be distinguished from others that do not appeal to Islam as a marker of identity. Importantly, Islamic parties are not immune to money politics or oligarchy. PKS, perhaps, has been the most disappointing to voters, as corruption scandals eventually dispelled the 'clean' image it had quite successfully cultivated.
} 
Political horse-trading in the wake of legislative elections requires compromises that can alter the programs on which the parties ran their election campaigns. Voters thus may suddenly see policies advanced by their chosen party that they had not bargained for. The influence of smaller parties with an Islamisation agenda, for example, largely rests on influencing their larger coalition partners, and this is a major concern for nationalist voters who have strong reservations about political Islam. The result is a lack of clarity about party policy from a voter's perspective, which undermines the principle of informed choice. On the other hand, an optimist might view power sharing among parties as a benign form of political consensus building within this multi-ethnic and multi-religious nation. The tendency to pair Javanese candidates with a politician from the outer islands (cf. the Jokowi-Kalla team), for example, suggests there is a genuine desire among the political class to cater to the interests of sectors of Indonesian society that are peripheral in ethnic terms, even if the practical motive may be electoral success.

So much for the formal constraints on political party's eligibility to contest elections in Indonesia, and on the relative standing of different parties today. But how do Indonesian political parties fund their increasingly costly operations, and what does this say about their democratic credentials?

\section{The Cost of Running a Party}

The cost of staffing offices in numerous provinces and in many hundreds of districts is very high. Expenses for promotional community projects and campaigning are also immense and rising, as campaigns become professionally run rather than relying primarily on the honorary work of volunteers. This 
"In America campaigns are not as expensive as in Indonesia, they can simply invite people to watch it on TV or read it in a newspaper, and most will. We however, have to mobilize the masses, feed them, and pay for their transport. It is exceedingly costly...a mass of people may be movable from Golkar to us (PD) or from PDIP to us, then they move back to PDIP - it is like a raffle - and all this has to be paid for. So the cost of doing politics in Indonesia is very high, beyond our capacity. The rules on...party contributions are not appropriate, businesses can only give up to 7 Billion [Indonesian Rupiah IDR, equivalent to c. US $\$ 700,000]$, and yet our need for campaign funding is much higher than in America." (Author's translation)

His comparison with the US situation may be somewhat hyperbolic, but Budisantoso certainly has a point. In addition to fully catered public events in hired public arenas, campaigns can involve vote buying with gifts or even cash. In Surakarta, for example, several individuals independently reported to me that they were offered around IDR 50,000 by so-called 'success teams' to vote for a specified party. In Bali several people reported to me that villages had received payments collectively. I could not follow this up, however, the Asia Foundation's Sandra Hamid also found that "more than 35 percent of voters confessed that they, or their families, had experienced vote buying” (Dominguez 2014). Indeed, a cynic might say that, in such a transactional political system, why should the public be the only ones to miss out on a payment?

Incumbents have an advantage because a cheaper option available to some of them is intimidation. Several government employees told me they were pressed hard by the regency administration to vote for the ruling party or face redeployment to a remote location. Other reports speak of pressure being put on student voters. ${ }^{5} \mathrm{I}$ am not in a position to judge the extent of such activity, and intimidation

${ }^{5}$ Personal intimidation is a significant instrument of power in the realpolitik of many countries, including Indonesia. This is often exercised in very clandestine ways and is rarely discussed by political commentators. For a report on a case of election intimidation of student voters, see: http://m. 
may not be very effective anyway. The same also goes for vote buying, given that voting is anonymous. Where does all the money for campaigning and operational costs come from?

\section{How Parties Raise Funds}

There are three sources of legitimate funding for political parties in Indonesia: member's contributions, state funding, and private donations. Members' contributions are hardly a significant factor any more in Indonesia and elsewhere, because parties worldwide have lost their mass base in recent decades. This is also true of new democracies. In Indonesia, party members who have a seat in the House of Representatives or are ministers must furthermore surrender about 15-25 per cent of their wages, but this is also a relatively small amount. ${ }^{6}$

Parties in most countries also receive some funding from the state, and on this count Indonesian parties are comparatively poorly provisioned. In 2001, the payments were IDR 1000 per vote, but this amount was reduced by 90 per cent in 2005, to IDR 21 million per seat, or some IDR 100 (about 10 US cents) per vote. During the same period there was a fivefold increase in campaign costs (PDIP figures; Mietzner 2013). ${ }^{7}$ In short, state support is now negligible.

The 2011 party law also allows for donations -1 billion IDR per annum (equivalent to USD 100,000) from individuals and up to 7.5 billion IDR from corporations. Actual donations clearly do not conform to these limits and not always made to parties. They also include payments to prominent individual party members. It would be foolish to assume that such donations are given free of strings attached. Current law requires parties to disclose donations, income and expenditures only in a single report endorsed by their own auditor, rather than having to open their accounts to public scrutiny. Illegal contributions and spending thus cannot be traced by revealing discrepancies between income and expenses. Titi Anggraeni, executive director of the Association for Elections and Democracy says that their research found legal sources of income covered less than 15 per cent of the operating expenses for political parties. A huge amount of unseen and illegitimate funding changes hands. This utter dependence on private funding has come to dominate the reality of Indonesian party politics (Cochrane 2013).

So where do the other 85 per cent come from, not to mention the money required for covering illicit expenses? To the best of my knowledge no reliable figures are available on the actual volume of funds obtained by political parties

aktual.co/politik/151449tragis-mahasiswa-di-malang-dipaksa-pilih-parpol-tertentu/comment (accessed on 1 October 2014).

${ }^{6}$ The chair of the Indonesian Community for Democracy (KID) confirms this practice. See: Kleden, Ignas 2014. 'Political parties and the question of financing.' Jakarta Post, 14 February 2014. ${ }^{7}$ For comparative information on party funding in Indonesia up to 2007, see Mietzner (2007). 
in a covert manner, for obvious reasons. In any case, it is much more important where the money comes from, how it is transferred, and whose interests it represents. My research thus far suggests that there are three types of political parties in Indonesia, each based on a different model for securing 'informal' private funding.

One type is sometimes mockingly referred to as partai milik pribadi or 'privately owned parties'. These are parties created from the outset to serve as a political tool for a private individual, who wants to gain power within the DPR or through the office of President, or both. Examples are Gerindra, the party founded by Prabowo with his billionaire younger brother Hasyim; the National Democrat Party (Nasdem) founded by Metro Group media tycoon Surya Paloh; and the Hanura Party of wealthy former general Wiranto and his media tycoon friend Hary Tanoe Soedibjo. In this kind of political party, the founders' economic and political control of the party is very explicit, though not necessarily absolute. Note the prominent role of media tycoons within this class of political actors, on account of their dual ability to influence public opinion as well as provide illicit campaign funds.

In the case of the 'private party' Hanura, the founder Wiranto is collaborating openly with a powerful financial ally. A similar scenario pertains to fellow ex-general SBY's Partai Democrat (PD). His party again is new and rather small, and was founded to be one man's political tool to allow him to run for president in 1999 - successfully, in this case. In both cases, the illustrious founders are wealthy former generals but not wealthy enough by far to pay for a massive election campaign without financial backers. Among 'private parties' the degree of power concentrated in the hands of the party chief thus depends in good part on the degree of his or her own, independent wealth. The leaders of directly billionaire-owned private parties do not need to make as many political concessions to openly visible or concealed financial partners as do 'front man' private party leaders like Wiranto and SBY. This can be positive, in that their programs can be more cohesive, but on the other hand, there are fewer checks and balances.

Apart from the new, one-person-focused parties, custom designed by billionaire stakeholders, with or without a prominent front man, there is a second model designed for informally funding larger, well-established parties. These are parties with a long history in Indonesian politics or with an indirect link to a historical mass base, such as the PKB's relationship to the vast Muslim organisation Nahdlatul Ulama (NU). This second model is based on a practice known as sewa kendaraan or 'hiring a vehicle,' whereby an established party is hired to serve temporarily as a political vehicle for a rich individual.

When I asked him to comment about the way billionaire businessman Aburizal Bakhrie had become Golkar's presidential candidate, even though he was an outsider, long-term senior Golkar figure Akbar Tanjung told me in an interview that 
"The politics of this is very much influenced by pragmatism and transactionalism, and the presence of money politics. Hence it is possible sometimes for a person, who was not raised in the environment of the party and who did not rise through the ranks, to stand for nomination with the aim of gaining a key position and thus to use that political party. These negotiations or political deals here also certainly require money." (Author's translation).

Similarly, but somewhat less controversial than the Golkar case, the billionaire owner of private airline 'Lion Air', Rusdi Kirana, recently 'hired himself a political vehicle' by becoming deputy chair of the PKB.

It is hardly a secret that nominations and elections for the position of chairperson or presidential candidate of large established parties involve substantial financial transactions. But there are also significant and ongoing tensions. The reverse-costs for Golkar, in this case, for example, were quite high and have given rise to intense resentment. Bakrie's handling of the 2006 Lapindo environmental disaster caused by one of his companies has made him widely unpopularin short, he has very low electability. Hence Golkar was a no starter in the 2014 presidential race. ${ }^{8}$ These problems with the Bakrie nomination show why the use of comparatively 'poor' but popular candidates as front men or women can be an attractive alternative to a billionaire donor/leader in today's media driven society. Indonesians are not yet accustomed to billionaires in politics, which for so long has been the playground of generals, and they tend to distrust their motives. This caveat applies equally to privately owned and hired parties as it does to the 'dynastic parties' I shall discuss next.

The Indonesian Democratic Party of Struggle (PDIP) represents a somewhat different model. This is a heritage party with a strong mass base in society and a dynastic element. Megawati Sukarnoputri has had a firm hold on this party as chairperson and was also its presidential candidate until 2014. PDIP is seen as the successor of the Indonesian Nationalist Party (PNI), led by her father, Indonesia's first president and hero of the independence struggle against the Dutch. Megawati's hold is largely based on dynastic political capital, which still does play a large though slowly diminishing role in Indonesia.

Golkar is also a heritage party, but its dynastic line was lost with the fall of Suharto and the subsequent retreat from politics of his family (known as the Cendana clan). The elite family of Prabowo Subianto too has a dynastic component, which I shall discuss at length in a forthcoming publication. Other examples include public figures like Meutia Hatta, presidential advisor and daughter of Mohammad Hatta, who was vice-president in the Sukarno era, and Yenny Wahid, daughter of former president, PKB founder and NU chair Abdurrachman Wahid. The dynastic element in Indonesian politics seems to be waning as the

${ }^{8}$ On Lapind, see: http://www.smithsonianmag.com/science-nature/the-worlds-muddiest-disaster1603529/?no-ist (accessed on 1 October 2014). 
economic imperative of money politics is becoming more dominant, but this could change again quickly under conditions of widespread public discontent.

As we already discovered, heritage parties like Golkar can and have been 'hired' as vehicles for politically ambitious billionaires. In the case of PDIP such a leadership change has not been possible so long as the personal status of Megawati Sukarnoputri as party leader has remained unassailable in the minds of followers. But neither has it been necessary. PDIP has had informal access to the immense wealth of Megawati’s husband, Taufik Kiemas, a business tycoon (now deceased). Less visibly the party has had support from other rich individuals and multinational corporations whose interests Megawati in turn has had to consider during her term as president, never mind the national interest. Overall, Megawati may best be referred to as an irreplaceable front person.'

PDIP's situation may now be changing. While Megawati is still chairperson, the party's successful presidential candidate, Jokowi, is closer to the model of a normal, that is, 'replaceable' front man, and his lack of sufficient independent wealth to pay for his own campaigns makes it imperative for him to have wealthy backers. He is said to have received support, for example, from Chinese business leaders for his 2013 campaign to become governor of Jakarta, according to the Indonesian National Survey Institute's Burhanuddin Muchtadi (pers. com.). He also received political support from businessman-politician Yussuf Kalla, and from Prabowo Subianto, who later became his rival for the presidency in a remarkable reversal. ${ }^{9}$ Jokowi may retain enough charisma to remain indispensable for PDIP for some time, which does give him some power of his own. His presidency could even mark the beginning of a new dynastic line within PDIP, providing of course that his popularity keeps him in office long enough and allows him to negotiate a policy package that will please the public as well as his financial backers.

All parties also raise funds from a host of non-dominant, secondary sponsors. Secondary sponsors receive specific favors more often than ongoing political support for their business ventures. Some choose to remain invisible while others publicly display their support for their political 'champions' (jago). Chinese businessmen are an interesting case. Once known for being secretive about their political affiliations, and prone to donating, in blanket fashion, to all major parties, some are now trying themselves at more direct and public political engagement, for example Jakarta’s (deputy) governor Ahok, thus questioning a long established ethnic division in Indonesia between political and economic power. ${ }^{10}$ Nevertheless, anti-Chinese sentiments among voters still place them at a disadvantage in a democratic political arena.

${ }^{9}$ 'Elite engineering gives birth to Jokowi's ascension.' The Jakarta Post, 19 November 2013. Available at: http://www.thejakartapost.com/news/2013/11/19/elite-engineering-give-birth-jokowi-s-ascension.html (accessed on 1 October 2014).

${ }^{10}$ This division is of course not absolute. There are also important non-Chinese economic players, some of whom I have mentioned. However, Chinese business tycoons still dominate the Forbes list 
Note that the above typology of political parties, based on their funding models, is intended merely as a way of identifying the basic features of a very complex political scenario. In reality, political parties in Indonesia all operate under similar conditions and what they have in common is much greater than what distinguishes them. These contemporary systemic conditions are not natural but the result of a particular and ongoing historical process with an uncertain future.

Comparison shows that these conditions are not unique to Indonesia or ASEAN. Media tycoon Silvio Berlusconi’s ‘Forza Italia' Party in Italy and, in Australia, billionaire Clive Palmer's Palmer United Party (PUP) remind us that western democracies are not far behind in this trend toward having billionaires come out of the closet and declare themselves openly as political players, on a 'private party' platform or, in other cases, by joining established parties. This is making money politics more blatant and legitimate, and changing the essential meaning of what we understand a political party to be (Miragliotta 2014).

To some extent the political consequences depend on the kind of billionaire we are dealing with. Programmes still do matter, and wealthy politicians can be voted out of office like all others. On the other hand, the conflation of political power and private ownership, in combination with a massive contemporary trend toward increasing inequality and middle-class decline (Diehm and Hall 2013; Pickety 2014), and with the increasing political influence of privately owned media, does raise the question whether this kind of system still can be described as democratic. Inglehart and Welzel's (2003) distinction between effective and electoral democracy is useful here, as a transitional concept. In the long run, however, a vital lack of effective democracy is likely also to undermine electoral processes.

Jeffrey Winters (2011) work on 'oligarchs' shows that large private financial interests exerting overt political influence to the point of conflating ownership and power is by no means a new phenomenon, though the sphere over which oligarchs exert influence today is unprecedented and increasingly global. Relationships between them and a range of ther globalising elite sectors remain complex and contested- (Rothkopf 200 2 he political rise of billionaires is oddly reminiscent of the various feudal systems that proceeded democracies in many countries, including Indonesia, in that the political rulers of feudal societies were also simultaneously the paramount owners of the means of production (primarily land in agrarian societies). The emerging ownership cartel in modern Indonesia is reflected in the fact that the 40 richest individuals' assets are equal to about 10 per cent of Indonesia's GDP (Winters 2013). For ordinary citizens, the only hope under a fully-fledged 'ruler-owner' system, feudal or hyper-modern, is the rise of a 'just king' (or ratu adil in the Javanese tradition), whose noble character is said to 
"[Power] used to be centralised. So whatever Suharto or his cronies said was done.... Now political power is divided into three. At the centre there is still power, resting with the ministers for example, but what remains is only one third. Then there is power in the DPR, because the DPR controls the budget and authorises. Then [thirdly], there are the Regions. So the strength of government is broken up. Things are decided by the DPR. No matter what the government says, the DPR can change it." (Author's translation)

Kalla's point is that the executive had supreme decision power and a monopoly on force prior to the amendment, but that now the deal making, the transactions rule the day. Political parties, even ruling coalition parties, need to broker broad alliances in the DPR - often on a case by case basis - in order to satisfy the specific needs of their political clients. This is a complex process known as 'politik transaksional'. Low-profile individuals who run powerful informal communication networks often manage these transactions. They are the majority makers who navigate laws through the DPR, they are the ones who broker deals for legislative amendments, budget allocations, contracts, and so on, at the behest of the major players. A major focal point of such political deal making is the influential DPR Commissions.

The most lucrative deals are about the allocation of government development contracts. Political parties back affiliated contractors and then embezzle funds, according to credible reports (Zaenal Arifin 2014). Various high placed sources have told me that less than half of infrastructure development funds reach their destination. This shows how money politics mermines public interest. 
Ibrahim Fahmy, program director at Transparency International Indonesia, notes similarly how "some big corporations lobby members of parliament, who then accept bribes in exchange for granting projects" (cited in Domínguez 2014). An example is the case of the governing Democrat Party's treasurer, Nazaruddin, who accepted bribes of almost three million USD in connection with tenders for the Southeast Asian Games. Meanwhile, the party's former chairman, Anas Urbaningrum, allegedly took 100 billion IDR in kickbacks to rig the lucrative contract for building a sports centre in Hambalang, Bogor. Their coalition partner, the PKS, had former president Luthfi Hasan Ishaaq face charges of bribery in the beef import case of February 2013. The main problem is that the anti-corruption body KPK and the courts prosecute only the corrupted officials, while the ones who corrupted them generally escape punishment.

Political transactions in Indonesia of course also accompany the accommodation of sometimes systemic, sometimes diverging foreign interests. Indonesia has been attracting an enormous amount of foreign investment in recent years. It is also an extremely important country strategically, especially in a context of growing c (nT) Station between the US and China, and associated military tensions (Gunn 2014). At stake is not just regional hegemony, but the larger question of unipolarity vs. multipolarity of the entire geopolitical order for the twenty-first century (Layne 2012).

\section{Solutions: Reducing the Sway of Money Politics}

The Corruption Eradication Commission (KPK), the DPR's ethics committee and NGOs like the Association for Elections and Democracy have all been suggesting reforms are needed to increase tax-payer funding for political parties, so as to reduce their dependence on billionaire sponsors (Devianti Faridz 2014). These calls are also echoed by academic commentators like Markus Mietzner (2013), in his recent book Money, Power, and Ideology: Political Parties in Post-Authoritarian Indonesia.

Would this work? Personally, I would say ‘no’ or, more precisely, it is naïve to assume this strategy will have any effect on its own. Providing parties with public funding is no guarantee against 'double dipping', that is, taking public money as well as private sponsors' money. In the competitive environment they inhabit, there is simply no such thing as a political party with too much money. Take the Australian case as an example: The public purse's contribution to political parties is now AUD 2.48 per vote received (USD 2.29) for both House of Representatives and Senate votes. The amount of public funding in 2010 was close to seven times higher than it was in 1984. This 'increased public funding' policy was well intentioned to remove the incentive for money politics and stop private money distorting the contest. It did not achieve this aim, however, because the legislation did not cap spending or limit private donations. Indeed, private 
donations grew enormously (Young 2013). The current inquiry into political corruption in Australian state of New South Wales also shows how overly intimate links between politics and business and a lack of appropriate checks may open the door to abuses of public office anywhere, not just in Indonesia and other ASEAN countries. I therefore would recommend that adequate public funding of political parties be supported by the following six additional measures (in Indonesia and elsewhere):

First and most important, it could be made a licensing condition for media companies that access to a generous quota of media space be provided free of charge to all qualifying political parties on all TV and Radio channels carrying news, as well as in newspapers, perhaps with a larger quota for parties that achieved more than say five per cent in the previous election; with time/space quotas kept moderate between campaigns, and raised during campaign periods. (A stratified funding model raises the possibility of 'cartelisation', whereby larger parties would have the advantage. The opposite would be an excessive proliferation of small parties, to the detriment of unitary governance. Much thus depends on how well a stratified funding model is calibrated to avoid these opposite risks). Equity principles ought to be observed for voluntary additional coverage given to particular parties and their policies by news media in reports or editorials. As it is, the rental market in commercialised public space is simply too expensive to compete in for parties whose programmes genuinely serve the public or run against the prevailing policy directions that are the embodiment of big money influence. Indeed, the overprized media estate market is a key mechanism for the maintenance of the current policy landscape.

Second, strict rules could be set to limit donations to parties, making both donors and political parties criminally and personally liable for any violations, instead of pursuing selected politicians only. Conflicts of interests due to activities before, during, or after a politician's term in office should be avoided. An example is the appointment of former ministers to lucrative 'reward positions' in companies whose interests they have served while in office. The case of the appointment of former Australian foreign minister, Alexander Downer, by Woodsite Petroleum comes to mind, given his involvement in securing the highly controversial Timor Gap Agreement to the benefit of this company; a case now brought before the International Court in den Haag by Timor Leste. Whatever one may think about this or any other particular case, even potential conflicts of interest can discredit a system of political representation.

Third, candidates convicted of vote buying or voter intimidation could face a life-long disqualification to stand for office. A further related point is that there is a need for improved voter education on what can be expected of political parties in a democracy.

There should also be strict limits on media ownership consolidation. Again Australia presents a striking example of how easily public opinion can be turned against governments on either side of politics where there is high 
media ownership concentration; Indonesia currently is still in a slightly better position with about seven major media owners.

Lastly, there needs to be concerted efforts-by parties to (re-)establish a mass base in civil society around important contemporary issues and challenges (of which there are many), and to set up internal procedures to ensure candidates are proposed for election on the basis of their talent, dedication, vision and, above all, compassion.

Some may object that I am just dreaming, that the political will for such reforms is entirely lacking. However, that only begs the question of whose will is done in today's democracies? The matter of political will in a commercialised polity largely comes down to the remnant autonomy of the political class and security enforcers relative to their dependence on donors, and on the relative degree of unity within the different camps.

On the global level, as everywhere, there is an urgent need for the political class to stand up and be counted, working united through the G20 and other channels. To hold transnational capital to its public responsibilities (such as paying taxes) is now beyond the capacity of individual nations. Conversely, it will be interesting to watch for progress in the commercial sector. Voluntary public responsibility initiatives promoted from within the business community and by private capital today may not always be without ulterior motives, but a new sense of responsibility seems to be emerging. Indonesia is leading the pack in this regard, as the first country to legislate a mandatory 'corporate social responsibility' program. To turn this into a paradigm will require a new, global consensus and responsible business leadership for sustainable prosperity.

In the interim, it is up to civil society to fill the gap. Social media is providing an affordable alternative route for political parties, and indeed for civil society groups, to access public space in Indonesia - reminiscent of use of new media in the Obama campaign. Between 1998 and 2008, households with a television increased almost threefold, but by June 2013 Indonesia also had almost 64 million active Facebook users and about 30 million Twitter users. In 2012 Jakarta became the world's most tweeted city, ahead of London, New York and Tokyo (Stott 2014). A recent European Union policy decision to maintain the freedom of the internet as a largely rent-free public space can be seen as a recognition of the key role of free or low-cost (online) media space to the future fate of democracy. Low-cost advocacy organisations are transforming contemporary political landscapes, by drawing market failures and governance failures to public attention (Karpf 2012).

More broadly, I agree with Ed Aspinall's (2013) assessment that, alongside the enormous and still growing influence of private capital over the political process, media space and the security sector, public agency also has been a force to be reckoned with in post-Suharto Indonesia. Religious organisations and civil society groups became politically engaged after 1998, and some of the good work done by the pro-democracy NGOs among them is deliberately 
cited in this article. Constant public debate on the issue of political corruption and the high profile of some of the cases pursued by the Corruption Eradication Commission are testimony to a hotly contested struggle for political accountability and justice driven ultimately by popular aspirations and the availability of low rent media.

In Indonesia, as elsewhere, the military also remains important for the containment line mentioned earlier, given the close relations that exist between the military and the political class in this country, as in many others. Herein I can only briefly touch on some key trends. Apart from overly intimate military-industry links and 'revolving doors' between associated elite sectors, the most serious concern today is a global trend toward a privatisation of security that runs in parallel to the private funding of representational political structures. In Indonesia the army forfeited its very prominent position in the political system and lost some of its bargaining power after 1998, especially since the 'reformasi' period also saw a proliferation of interest-based paramilitary groups forming along the fringes of the security apparatus, with diverse political or ethnic allegiances and sometimes with clandestine links to regular forces. Most major political parties and also civil society organisations maintain their own private security apparatus. Such privatisation of force, if it escalates, would surely spell the end of democracy, as we know it.

\section{TOdAY INDONESIA, TOMORROW THE WORLD}

In conclusion, money politics in Indonesia is creating a system whereby major financial interests maintain an order that is largely to their liking, while making only modest concessions to the interests of the wider public. This is a global phenomenon in every sense of the word. In a recent address at a retreat for the leadership of the German Social Democratic Party, Jürgen Habermas issued this warning:

"Those who do not wish for a modern form of feudalism to spread under the mantle of democracy must direct their gaze to examine the agenda of world economic politics, which today largely determines the amount of wiggle room there is for exerting political influence over the setting of living conditions within democratic societies. Neoliberalism replaces democracy with a legalistic state devoid of social protections." (Habermas 2014: 86, this author's translation).

Some may hope to sleep better at night by dismissing such concerns, arguing that things still seem ok, whosoever it may be that rules the roost, at least for the time being. Such complacency only begs the question: how ethical and civilised is the rule of money today, and how ethical and civilised can it remain or become, especially now that some members of the moneyed elite are entering directly into the limelight of the political arena? 
The quest for personal profit, which is the ruling spirit of the commercial world, is too reductionist a perspective on politics in my opinion, even when such instrumentalism gains popular appeal, as it has. In Indonesia many voters now apply the same reductionist logic of transactional politics, by using the degree of 'trickle down effect' to measure and compare the performance of political parties - never mind who their owners or backers may be, as do many voters in other countries. The problem is that such 'voter transactionalism' not to mention the transactionalism of the ruling elite - encourages irrational biases and a spirit of short-termism in state policy settings. The resulting policy deficit prevents us from responding rationally to the urgent resource challenges humanity now faces, and thus sets the scene for a violent race to the bottom. Public life in today's world is simply not sustainable if it relies solely on an institutionalisation of avarice. The advance of powerful private sector players into the realm of politics in some ways may reflect the dawning of this realisation upon them.

\section{Acknowledgements}

Research for this article was carried out with funding from the Australian Research Council.

\section{References}

Aspinall, Edward. 2013. Popular agency and interests in Indonesia’s democratic transition and consolidation. Indonesia 96, 101-121.

Basedau, Mathias and Stroh, Alexander. 2008. Measuring Party Institutionalisation in Developing Countries: A new research instrument applied to 28 African Political parties. GIGA Working Paper No 69. Hamburg: German Institute for Global and Regional Studies.

Cochrane, Joe. 2013. Plague of corruption rises anew in Indonesia.' New York Times. 30 May 2013. Available at: http://www.nytimes.com/2013/05/31/world/asia/31ihtindonesia31.html (accessed on 1 October 2014)

Devianti, Faridz. 2014. Indonesia's political parties forced to raise funds via corrupt means. Channel News Asia, 3 April 2014. Available at: http://www.channelnewsasia. com/news/asiapacific/indonesia-s-political/1057816.html (accessed on 1 October 2014)

Diehm, Jan and Hall, Katy. 2013. Middle class jobs, income quickly disappearing. The Huffington Post, 6 June 2013. Available at: http://www.huffingtonpost.com/2013/ 06/06/middle-class-jobs-income-_n_3386157.html (accessed on 1 October 2014)

Domínguez, Gabriel. 2014. Corruption fears loom over Indonesian elections. Deutsche Welle, 27 February 2014. Available at: http://www.dw.de/corruption-fears-loomover-indonesian-elections/a-17460529 (accessed on 1 October 2014)

Duverger, Maurice. 1956. Political Parties. London: Methuen.

Gunn, Geoffrey C. 2014. Indonesia in 2013: Oligarchs, political tribes, and populists. Asian Survey 54 (1), 47-55. 
Guriev, Sergei M. \& Andrei, Rachinsky 2005. The Role of Oligarchs in Russian Capitalism. Journal of Economic Perspectives 19 (1), Winter 2005.

Habermas, Juergen. 2014. Fuer ein starkes Europa - aber was heisst das? Blaetter fuer deutsche und international Politik March Issue.

Hoffman, David E. 2001. The Oligarchs: Wealth and power in the new Russia. New York: Public Affairs.

Huntington, Samuel P. 1991. The Third Wave: Democratization in the Late Twentieth century. Norman and London: University of Oklahoma Press.

Inglehart, Ronald and Welzel, Christian. 2003. Political culture and democracy: analyzing cross level linkages. Comparative Politics 36 (1), 61-79.

Karpf, David. 2012. The MoveOn Effect: The Unexpected Transformation of American Political Advocacy. London: Oxford University Press.

Layne, Christopher, 2012. This time it's real: The end of unipolarity and the pax Americana. International Studies Quarterly 56, 203-213.

Lijphart, Arend. 1968. Typologies of democratic systems. Comparative Political Studies $1,3-44$.

Lipset, Seymour M. and Rokkan Stein (eds.) 1967. Party Systems and Voter Alignments: Cross National Perspectives. New York: Free Press.

Mietzner, Marcus. 2007. Party financing in post-Soeharto Indonesia: between state subsidies and political corruption. Contemporary Southeast Asia 29(2), 238-263.

Mietzner, Marcus. 2013. Money, Power, and Ideology: Political Parties in Post-Authoritarian Indonesia. Singapore: NUS Press.

Mietzner, Marcus. 2013. Political party financing in Indonesia is a recipe for disaster. Strategic Review Oct-Dec 2013. Available at: http://www.sr-indonesia.com/in_the_ journal/view/political-party-financing-in-indonesia-is-a-recipe-for-corruption?pg=2 (accessed on 1 October 2014).

Miragliotta, Narelle. 2014. The WA senate election and the rise of money in Australian politics. The Conversation 15 April 2014. Available at: http://theconversation.com/ the-wa-senate-election-and-the-rise-of-money-in-australian-politics-25477 (accessed on 1 October 2014).

Murphy, Ann Marie. 2010. US rapprochement with Indonesia: from problem state to partner. Contemporary Southeast Asia 32(3), 362-87.

Panebianco, Angelo. 1988. Political Parties. Cambridge: Cambridge University Press.

Pickety, Thomas. 2014. Capital in the Twenty-First Century. Cambridge, MA: Belknap Press.

Reuter, Thomas. 2010. Spiritual imagination and societal change in Indonesia: the prophecies of King Jayabaya. In Sebastian Job and Linda Connor (eds.), Anthropology and the Ends of Worlds, p. 34-45. Sydney: Department of Anthropology, University of Sydney.

Rhoden, Thomas. 2013. Thailand's oligarchs are fighting. New Mandala, 11 December 2013.

Rothkopf, David. 2008. The Global Power Elite and the World They Are Making. New York: Farrar, Straus and Giroux.

Sartori, Giovanni 1976. Parties and Party Systems: A Framework for Analysis. Cambridge: Cambridge University Press.

Sachsenroeder, Wolfgang. 2014. Party Politics in Southeast Asia - Organization Money Influence. Smashword e-book Publications. Available at: https://www.smashwords. com/extreader/read/474999/4/party-politics-in-southeast-asia-organization-moneyinfluence (accessed on 1 October 2014). 